\title{
Phenomena Disturbing European Security and Tasks for Future Research
}

\author{
D. Procházková* \\ Czech Technical University in Prague, Faculty of Transportation Sciences, Praha, Czech Republic \\ *Corresponding author: prochdan@fd.cvut.cz
}

DOI: $10.2478 / \mathrm{v} 10158-012-0031-2$

\begin{abstract}
Based on the concept that Europe and its parts are represented by the model "System of Systems", denoted as a human system, the in-depth study of disasters and disasters' management reveals the tasks for future security research. The formulation of tasks for research is based on the philosophy that each responsible government should protect their inhabitants daily and especially during critical situations. The outputs show that European citizens are very threatened by organisational accidents, the causes of which are human behaviour defects and, mainly, human management defects on all levels of government.
\end{abstract}

KEY WORDS: Safety, security, disaster, disaster management, future research tasks.

\section{$1 \quad$ INTRODUCTION}

The security situation in Europe, the world and in each territory continuously changes with time, and therefore, it is necessary to form a new safety culture especially taking into account the actual knowledge and experiences with interdependences among the public assets leading to extreme social crises (in history, e.g., great famines). Due to the historical development there are: a lot of preventive and mitigating measures that have been applied in practice by legal rules, technical standards and norms, and public instructions; response systems; and renovation methods. However, it is true that their effectiveness decreases with time, because new risks emerge and territory and human vulnerabilities increase in all domains.

The performed research comes from the systematic concept of reality and its aim is systematically to create Europe as a safe community that has a highly sustainable potential. Europe stands as a significant world power if it ensures the security of itself and of its vicinity, which, in the globalization era of the world, is only possible by using a human system management based on a strategic, systemic, and proactive system of systems management (Procházková, 2012a; Procházková et al., 2012). To enable the solution to most present problems the concept used is complex. The paper summarizes the results of disaster research and disasters' management research in Europe. On their basis, it identifies the shortages in disaster management, forms the tasks for the removal of serious shortages and also proposes the directions in which the following research should head, so that Europe would systematically create a safe community and build a background for sustainable development. 


\section{PRIMARY FINDINGS AND PRINCIPLES OF RESEARCH OF DISASTERS AND DISASTERs' MANAGEMENT}

The present goal of humans is to live within a safe space, and therefore the UN formulated the aim of a "safe human system" in 1994 (United Nations, 1994) and the EU "safe community" in 2004 (EU, 2004). In agreement with the EU and UN proclamations and the professional knowledge it is necessary for the conservation and sustainable development of a human society to create a safe territory. With regard to present knowledge we should consider that we want to build a safe, open, and dynamically variable system that is a complex system, the model of which is a system of systems (SoS), i.e., several overlapping systems (Procházková, 2012b).

The security and development of both humans and the human system are troubled by disasters, i.e., internal or external phenomena that lead or from a certain size can lead to damage, harm, and the loss of humans and human system assets. This means that human system safety (i.e., a set of measures and activities ensuring the security and development of the above-mentioned objects) must consider both the processes, actions, and phenomena that are under way in human society, environment, the planetary system, galaxy and other higher systems, and also human management acts. Therefore, for safety reasons, we must negotiate with risks of a different origin and kind. The research performed under the FOCUS project (Procházková et al., 2012) deals with the principles of negotiation with risk at all stages of its mitigating and managing in selected sections of human system management, and it gives tools in favour of the public administration for public affairs' governance because it is responsible for territory governance and conditions; especially, it concentrates on EU governance.

On the basis of current knowledge it is not possible to solve significant problems of a complex system, which is every area including also the EU and Europe, by reducing complex problems to a set of simple problems, because, in this way, we neglect the nonlinearities and various interdependencies that create the specific couplings which are the causes of risks across systems, among partial systems, between the systems and their vicinities, etc.

Current knowledge shows that it is necessary to deal with the problems on the basis of the systemic concept of reality, which is based on systemic (holistic) thinking, the typical feature of which is focusing on the whole view of a system and on research on the relationships among their individual parts. The characteristics of systemic thinking are: to see both the whole and the details at the same time; to focus on the dynamics of processes; to pay attention to relations, associations and interactions; to take into account the roles of feedback; to consider the relativity of possible situations; and to think in a long-term way. A system according to its core means more than only a sum of its parts, and, therefore, stress is put on: the study of the interactions and associations; non-linear thinking; interactions; inductions; feedback; and experiments or realistic simulations. For example, feedback causes non-linearities in the system's behaviour that is not predictable, and, therefore, it is not possible to use the common prognostic methods for the identification of the possible states of a system.

In engineering practice there are used for the characteristic and management of: simply organized units the results of analytic solutions; composite systems (in practice the term construction is used) that are understood as a representation of elements that are organized and connected in a certain way and because of a proper structure they fulfil certain functions, the results of statistical solutions based on analytic functions, the parameters of which are variable in a certain interval, which is a reflection of various possible states / variants of the system behaviour; complex systems, the results of simulations and their optimization. The reason for the last mentioned approach is in reality that the complex systems 
are aggregates with many components (often systems too) that interact together and are organized in several levels, which results in us observing: suddenly emerged behaviour features that are not possible to obtain from the knowledge of the components' behaviour (so-called emergent behaviour); hierarchy; self-organization; and various management structures, which all together seem to be chaos. Present knowledge shows that in such cases it is necessary to take a multidisciplinary and interdisciplinary approach. For their management it is then necessary to use the multi-criteria approaches, i.e., to use several criteria, and to also consider the cross-sectional risks (Procházková, 2012b; Procházková et al., 2012). For the solution of their problems the tools based on the theory of chaos (Ott, 2012), theory of fuzzy sets (Zadeh, 1975), complexity theory (Gleick, 1996; Lucas, 2006; Mayers, 2009), theory of possibilities (Demster, 1967; Shafer, 1976) exist. Since Europe belongs to the developed parts of the world and the EU has ambitions to be a world power, it is necessary for it to build its politics on the current knowledge.

The systematic research of disasters, the summary of which is based on more than 5000 professional works, historical catalogues, databases, archives is in works (Procházková, 2011, 2012c, 2012d) revealed that we must consider the following disaster types as being the results of processes:

- In and out of the Earth: natural disasters - avalanches, earthquake, floods, drought, strong wind, volcanic activity, land slide, rock slide etc., land erosion, desertification, fundament liquefaction, sea floor spreading, etc.;

- In the environment including humans, animals and plants - illnesses;

- In the human society separated to:

- Unintentional: involuntary human errors -in operations and in management;

- Intentional: mutual improper behaviour of an individual or groups of individuals: wrongful appropriation of property; killing a human; bullying; religious and other intolerance; criminal acts such as: vandalism and illegal business, robbery and attacking, illegal entry, unauthorized use of property or services, theft and fraud, intimidation and blackmail, sabotage and destruction, terror against individuals, terrorist attacks; local and other armed conflicts; intentional disuse of technologies, such as: improper application of CBRNE substances; data mining from social networks and other cyber networks used for psychological pressure on a human individual; incorrect governance of public affairs: corruption; abuse of authority; and the disintegration of human society into intolerant communities.

- Which are connected with human activities: incidents; near miss; accidents; infrastructure failures; technology failures; loss of utilities, etc.;

- That are reactions of the Planet or the environment to human activities: man-made earthquakes; disruption of the ozone level / layer; greenhouse effect; fast climate variations; contaminations of air, water, soil and rock; desertification caused by human bad river regulation; drop of the diversity of flora and fauna (animal and vegetal) variety; fast human population explosion; migration of large human groups; fast drawing off of renewable sources; erosion of soil and rock; land uniformity, etc.;

- Connected with inside dependences in the human system and its surroundings separated into:

- Natural: stress and movements of territorial plates; water circulation in environment; substance circulation in the environment; the human food chain; planet processes; interactions of solar and galactic processes;

- Human established: human society management; flows of raw materials and products; flows of energies; flows of information; flows of finances, etc. 
In the social domain for reasons of internal relations the monitored adverse effects are put together into the following groups:

- Subsequent crime and other offences. The group includes: vandalism and illegal risk behaviour, robbery raids and attacks, property crime, killing and rioting;

- Tax fraud and fraud. The group includes: tax fraud, fraud;

- Damage to the customs laws, including: customs fraud, smuggling of prohibited goods;

- Illegal access to information systems. The group includes: data theft or data changes, espionage, partial fraud - forgery of documents, partial terrorist attacks, data mining from social networks leading to psychological pressure on people, bullying;

- Corruption and serious economic crime, including money laundering, extortion and humiliation. The group includes: corruption, abuse of authority;

- Society disintegration into intolerant groups. The group includes: religious and other intolerances.

Due to lack of data there are not considered: child labour, sabotage, infringement of law by government agencies, maritime piracy, severe negligence with criminal responsibility, misuse of postal services, an anonymous notice of alarming information, environmental crimes including pollution, and violations of security regulations.

\section{DATA AND METHODS OF SPECIALISED RESEARCH}

For the investigation of disasters and level of disasters' management original data and results of special projects were used, e.g. Switzerland - the PLANAT project, US - FEMA projects, Canada, the Netherlands, EMA (Australia), OCHA, the Czech Republic, IAEA, OECD, UN etc. - real references are in Procházková (2011) and in materials quoted in. For obtaining the original results there were also used:

- Historical catalogues, databases, archives and original papers on phenomena that caused harm and losses to public assets within the time period from historical times up to now (floods, earthquakes, chemical accidents, epizootic, epidemic, electroenergy net failure) that obtained very detailed results;

- Different methods, from very simple ones to scientific ones.

The outputs described in the next paragraphs are created through pure scientific methods (analysis and synthesis of directly obtained or published results on disasters; specific investigation of disasters by analytical and heuristic methods with step in which the heuristic methods were at first tested on real data to see if they are suitable for security tasks solutions; specific investigation of the level of disaster management with regard to human survival, security and development with the help of special logical tools tailored for FOCUS project targets (Procházková, 2012d). Detail descriptions of data and methods used for the original results derivation, with references, are in publications quoted in the appropriate places.

\section{SUMMARY OF OUTPUTS OF INDIVIDUAL STUDIES OF DISASTERS AND DISASTERS' MANAGEMENT}

The detailed study on disasters and disasters' management in the EU (Procházková et al., 2012) was concentrated into ten domains, the outputs of which are concisely summarized 
in papers (Procházková et al., 2012; Binková et al., 2012; Procházková, Mozga, Richter, Procházka, Z. \& Procházka, J., 2012; Procházková, Richter, Procházka, Z. \& Procházka, J., 2012; Procházková \& Kopecký, 2012; Procházková \& Pešková, 2012; Procházková \& Říha, 2012a,b,c; Procházková, Šenovský \& Mozga, 2012; Procházková, Bartlová \& Šenovský, 2011; Procházka, J., Procházka, Z., Ř́ha \& Procházková, 2012; Procházková, Šenovský \& Bartlová, 2012). The work (Procházková et al., 2012) also obtains the results of a theoretical study from which it follows that the advanced EU security concept: is based on the systemic (holistic) thinking, the typical feature of which is the focusing on the whole views at systems and on research of relations among their individual parts; uses the proactive approach; apples all hazard approach (FEMA, 1996); and respects the co-existence of overlapping systems (Procházková, 2012b). At its realisation it is necessary to sophistically manage the disasters that damage the security of communities and their assets, i.e., to apply measures and activities of prevention, preparedness, response and renovation. For practical purposes good technical solutions based on recent findings and experiences and correctly aimed governance of public affairs supported by legislation with sufficient legal force, finances, qualified human personnel and material base are necessary.

\section{LIST OF SECURITY CHALLENGES}

Synthesis of results obtained by detailed studies of disasters and disasters' management described in (Procházková et al., 2012; Binková, Horáková \& Procházková, 2012; Procházková, Mozga, Richter, Procházka, Z. \& Procházka, J., 2012; Procházková, Richter, Procházka, Z. \& Prochazka, J., 2012; Procházková \& Kopecký, 2012; Procházková \& Pešková, 2012; Procházková \& Ř́ha, 2012a,b,c; Procházková, Šenovský \& Mozga, 2012; Procházková, Bartlová \& Šenovský, 2011; Procházka, J., Procházka, Z., Ř́ha \& Procházková, 2012; Procházková, Šenovský \& Bartlová, 2012) is summarized in Table 1.

Table 1: Deficits at disasters' management.

\begin{tabular}{|c|c|}
\hline $\begin{array}{l}\text { SECURITY } \\
\text { ITEMS }\end{array}$ & RESEARCH RESULTS \\
\hline $\begin{array}{l}\text { Security } \\
\text { challenges } \\
\text { that can be } \\
\text { considered } \\
\text { to have } \\
\text { a big impact } \\
\text { in the } 2035 \\
\text { time frame } \\
\text { and currently } \\
\text { are not } \\
\text { sufficiently } \\
\text { addressed } \\
\text { in the planning } \\
\text { of research }\end{array}$ & $\begin{array}{l}\text { The list of following disasters is necessary to be supplemented } \\
\text { by phenomena in: } \\
\text { - Nature: geomagnetic storms; soil salinization, fall of a cosmic body, } \\
\text { sand storms, and sudden change of weather (cold wave or heat wave); } \\
\text { Technology: organising accidents in technological facilities, accidents } \\
\text { connected with biotechnologies, disuse of technologies (nuclear, nano } \\
\text { and IT), disuse of genetic engineering, and disuse (abuse) CBRNE } \\
\text { agents; } \\
\text { - Human activities' organisation: education infrastructure breakdown, } \\
\text { research infrastructure breakdown, breakdowns (organising accidents) } \\
\text { in public governance, defects of supply chains; } \\
\text { - Environment (including human): stress and movements of territorial } \\
\text { plates; rapid natural subsidence of surface, defects in water circulation } \\
\text { in environment; defects in substance circulation in environment, defects } \\
\text { in human food chain, defects in planetary processes, planet defects } \\
\text { as results of interactions of solar and galactic processes, incurable } \\
\text { diseases in systems of humans, animals and plants; } \\
\text { Environment reactions to human activities: artificial surface subsidence } \\
\text { due to undermining, and interaction due to militarization of outer space; }\end{array}$ \\
\hline
\end{tabular}




\begin{tabular}{|c|c|}
\hline & $\begin{array}{l}\text { - Society: illegal production and distribution of narcotics and psychotropic } \\
\text { substances, illegal migration, proliferation of weapons of mass } \\
\text { destruction. }\end{array}$ \\
\hline $\begin{array}{l}\text { Most severe } \\
\text { security } \\
\text { challenges } \\
\text { that should } \\
\text { be addressed } \\
\text { by research } \\
\text { planning } \\
\text { in the } 2035 \\
\text { time frame }\end{array}$ & $\begin{array}{l}\text { The disaster order with regard to the impact severity is: } \\
\text { - Nature: fall of a big cosmic body on Europe, extreme earthquake, } \\
\text { extreme floods, extreme forest fires, and extreme drought; } \\
\text { Technology: beyond design accident with presence of radioactive } \\
\text { substances, beyond design accident with presence of substances mutagenic, } \\
\text { carcinogenic and harmful to reproduction; } \\
\text { - Human activities' organisation: corruption, disuse of power, } \\
\text { insufficient respect to public interest, education infrastructure } \\
\text { breakdown, research infrastructure breakdown, breakdowns (organising } \\
\text { accidents) in public governance, defects of supply chains; low robust } \\
\text { technical and finance infrastructure that causes long-term outage } \\
\text { of electrical infrastructure, long-term stoppage of drinking water supply, } \\
\text { long-term outage of food and long-term financial market disorder; } \\
\text { Environment (including human): disruption of water circulation } \\
\text { in environment, disruption of substance circulation in environment, huge } \\
\text { pandemics and epidemics, and incurable diseases of humans, animals } \\
\text { or plants and across them; } \\
\text { Environment reactions to human activities: contamination of air, water, } \\
\text { soil and rock missive's, uncontrolled human population explosion, } \\
\text { migration of large groups of people, the militarization of space, } \\
\text { and climate variations; } \\
\text { Society: abuse of power, corruption, decay of human society } \\
\text { into intolerant groups, abuse of technology, abuse of authority, illegal } \\
\text { access to information systems, cybercrime, terrorist attacks, corruption } \\
\text { in government and public administration, including the political scene, } \\
\text { serious economic crime including money laundering and tax evasion, } \\
\text { trafficking with human beings and illegal migration, illegal production } \\
\text { and distribution of psychotropic substances, extremism, and all forms } \\
\text { of discrimination and intolerance. }\end{array}$ \\
\hline $\begin{array}{l}\text { Challenges } \\
\text { for future } \\
\text { security } \\
\text { research } \\
\text { for prevention, } \\
\text { preparedness, } \\
\text { response, } \\
\text { and renovation }\end{array}$ & $\begin{array}{l}\text { - To implement the system of management based on integral safety } \\
\text { and to improve the prevention, preparedness, response, and renovation; } \\
\text { - To build a systematic approach for a response to disasters (individual } \\
\text { Member States have the systems of response on various levels); } \\
\text { - Especially to improve the response to critical situations because extreme } \\
\text { disasters cause big economic and social impacts (see lesson learned from } \\
\text { Fukushima accident). They actually affect infrastructure (buildings, } \\
\text { transport, energy and water supports), which represents specific damage } \\
\text { and losses in densely inhabited areas; } \\
\text { - To target the crisis management in the case of extreme situations is necessary; } \\
\text { - To process norms and standards for infrastructures that will: ensure their } \\
\text { sufficient capacities; enhance their robustness and resiliency; } \\
\text { - To upgrade the sector and cross-sector management - to consider } \\
\text { the cross-sectional risks (systemic management) and to put the cross- } \\
\text { sectional risks (systemic engineering) under control; } \\
\text { - To compile robust measures to prevent the disuse of technologies; } \\
\text { - To introduce early warning systems in the case of disasters for which } \\
\text { there are known symptoms that enable warning; }\end{array}$ \\
\hline
\end{tabular}




\begin{tabular}{|c|c|}
\hline & $\begin{array}{l}\text { To prepare tools for systematic regulation of the recovery process; i.e. } \\
\text { a recovery plan and plan for the prevention of losses at renovation; } \\
\text { - To improve the humanitarian assistance in the case of extreme disasters. } \\
\text { - To implement the systematic use of disaster insurance policies; } \\
\text { - To improve the attention to land degradation - lack of European } \\
\text { legislation and objectives of soil protection; } \\
\text { To improve the EU preparedness for climate change because it is lagging } \\
\text { behind in the sphere of adaptation (in contrast to the absurd emphasis } \\
\text { on the causes of the greenhouse effect); to increase attention } \\
\text { to adaptation in a cross-border dimension (e.g. the possibility } \\
\text { of international coordination and construction of dams and reservoirs) - } \\
\text { attention paid not only to economic, but also to social criteria; } \\
\text { To upgrade management of social disasters - Prevention is not systematically } \\
\text { carried out for any of the social disasters, prevention is often declared } \\
\text { by signed treaties, conventions, treaties or bilateral/multilateral agreements } \\
\text { but in reality no effective tools. It is necessary to improve: close } \\
\text { interdisciplinary cooperation of all parties involved at national level } \\
\text { and consistency with other central institutions within the EU states; } \\
\text { and sharing good practice, continuing education and training of experts } \\
\text { responsible at the pan-European level. Preparedness for coping with the given } \\
\text { disasters is the most well established and best on a theoretical level but } \\
\text { the level of practice is greatly affected by the economic stability of a particular } \\
\text { Member State; and level detection (intelligence services, technical means, } \\
\text { and the level of experts...) is variable and not interconnected. Because } \\
\text { of a highly unacceptable impact on the current situation in EU countries } \\
\text { having long-term consequences of an economic crisis, it is necessary to find } \\
\text { an effective tool for inhabitants to survive and for the stabilization } \\
\text { of the economic situation that evocates a lot of followed disasters; } \\
\text { To upgrade the process management - type "just in time" is not suitable } \\
\text { for goods, measures and activities that are important for human survival. }\end{array}$ \\
\hline $\begin{array}{l}\text { Related main } \\
\text { vulnerabilities } \\
\text { to be addressed } \\
\text { for future } \\
\text { security } \\
\text { research }\end{array}$ & $\begin{array}{l}\text { - Most infrastructure and objects are only protected to the size of design } \\
\text { disaster, i.e. at extreme disaster sizes they fail, which represents } \\
\text { a specific threat for densely inhabited areas. The situation can be made } \\
\text { worse at the coast with the rising of the sea levels; } \\
\text { - The insufficient level of civil protection in critical situations } \\
\text { that is ensured by the public administration of states; } \\
\text { - The low support to human daily needs from the public administration } \\
\text { of states; } \\
\text { - The incapability of inhabitants to take care of himself/herself and his/her } \\
\text { family, to secure his/her property, to have basic food and water } \\
\text { for at least } 24 \text { hours; } \\
\text { - The incorrect behaviour of humans in critical situations; } \\
\text { - Strategic and long-term approach is not systematically included } \\
\text { into the territorial planning on both the continents and the coastal areas, } \\
\text { including transport, regional development, industry, tourism, and energy } \\
\text { politics; } \\
\text { - Low attention to land degradation - lack of European legislation } \\
\text { and objectives of soil protection; } \\
\text { No sufficient EU preparedness for climate change, because it is lagging } \\
\text { behind in the sphere of adaptation (in contrast to the absurd emphasis }\end{array}$ \\
\hline
\end{tabular}




\begin{tabular}{|c|c|}
\hline & $\begin{array}{l}\text { - Lack of knowledge on: stress and movements of territorial plates, rapid } \\
\text { natural subsidence of surface, water circulation in environment, } \\
\text { substance circulation in environment, human food chain, planet } \\
\text { processes, interactions of solar and galactic processes; } \\
\text { - Low attention to adaptation in cross-border dimensions } \\
\text { (e.g. the possibility of international coordination and construction } \\
\text { of dams and reservoirs) - attention to economic and social criteria; } \\
\text { - The knowledge on the vulnerabilities of protected assets at different } \\
\text { disasters is only fragmental; } \\
\text { - No targeted crisis management for critical situations that can be caused } \\
\text { by: beyond design nuclear accident, long-term outage of electric energy } \\
\text { supply, long-term stoppage of drinking water supply, long-term shortage } \\
\text { of food supply, and long-term failure of the financial infrastructure; } \\
\text { - The deficiency of early warning systems in the case of disasters } \\
\text { for which there are known symptoms that enable the warning; } \\
\text { - Lack of technical resources, inadequate knowledge and training } \\
\text { of managerial staff, poor response management and lack of finances; } \\
\text { Lack of supply chain organisation at emergency and critical conditions; } \\
\text { - In many cases not enough care is given to prevent human errors } \\
\text { in processing plants and public affairs governance. }\end{array}$ \\
\hline $\begin{array}{l}\text { Related main } \\
\text { knowledge } \\
\text { gaps } \\
\text { to be addressed } \\
\text { for future } \\
\text { security } \\
\text { research }\end{array}$ & $\begin{array}{l}\text { - Missing the systematic collection of data on disasters of all types } \\
\text { and their impacts; } \\
\text { - No in-depth research based on data - key step - Missing data catalogues } \\
\text { for the disasters, qualified monitoring, systematic detection systems, } \\
\text { and systematic research. Special attention must be paid to social disasters } \\
\text { because data for research are pure - collection and processing of data } \\
\text { are at a low level from a methodical viewpoint, and therefore, it is necessary } \\
\text { to create: consistent data sets, effective mutual consultation and co-ordination } \\
\text { of procedures and their flexible adaptation to the rapidly evolving global } \\
\text { (trans-national) conditions that bring new threat scenarios, and, therefore, } \\
\text { it is necessary to apply the adequate methods determining the reliable } \\
\text { scenarios for decision-making with the aim to upgrading the security; } \\
\text { Missing knowledge for a solution to the lack of: drinking water, raw } \\
\text { materials, resources, energy, and food in the case of uncontrolled human } \\
\text { population explosion and the migration of large groups of people; } \\
\text { Missing tools for robust crisis management in the case of extreme disasters; } \\
\text { - No verification of every result, before its implementing in practice } \\
\text { by a public management opponent and by real experts who demonstrate } \\
\text { professionalism, objectivity and support of public interests - the way } \\
\text { how to avoid the influence of lobbyists; } \\
\text { No specification of standard methods for defining the scenarios } \\
\text { for the identification, analysis, assessment, management of risks } \\
\text { and dealing with risks are defined, no standards guaranteeing } \\
\text { that the results of different methods are comparable; } \\
\text { No data and methods for investigation of interdependences, rules of co- } \\
\text { existence of overlapping systems and of management and trade-off } \\
\text { with cross-sectional risks. }\end{array}$ \\
\hline $\begin{array}{l}\text { Proposed type } \\
\text { of future }\end{array}$ & $\begin{array}{l}\text { - Monitoring of all kinds of disasters and their impacts; } \\
\text { - To find a way how to implement in practice the strategic management }\end{array}$ \\
\hline
\end{tabular}


security

research of integral safety that is systemic and proactive and is not influenced by lobbyists and other pressure groups;

- To find a way how to implement the strategic territory safety management in a dynamically variable world in which the aspects connected with the following will be taken into account:

- Human lives and health as a protection of the physical body, food, drinking, comfort, homeland;

- Human security as protection against psychological harm and loss of security;

- Property as protection in the case of: buildings and fittings - loss, damage, domestic animals - death loss, loss;

- Public welfare as protection against: deterioration in the atmosphere among humans, and the loss of security;

- Environment as protection of: air, surface water, ground water, soil, rocks, landscape, forest, flora and fauna;

- Infrastructures and technologies as protection in the case of the failure of: energy supply (electricity, heat, gas), drinking water supply, utility water supply, sewage system, the transport network, cyber infrastructure (communication and information networks), the banking and financial sector, emergency services (police, firefighters, paramedics), essential services in the area (food supply, waste disposal, social services, funeral services), industry, agriculture, and state and local governments, i.e., of area management and management of human society. To compile principles of continuity plans and contingency plans.

- To find a way how to arrange the stability of the financial and banking sectors in dynamically variable words;

- To find a way how to implement professional knowledge for the benefit of the public interest;

- To find a way how to prevent big impacts of the brain drain and the exodus of professionals, i.e. how to create experience databases;

- To find a way how to upgrade: the co-operation in security research, the implementation of existing directives and legislation, and the individual response tools of the EU to appurtenant disasters;

- To find a way how to establish: effective tools and legislation in the prevention, preparedness, response and renovation (e.g. with incorrect governance of public affairs to force sanctions); qualified research based on real qualified data; and corresponding levels of education;

- To ensure the collection of qualified data (monitoring, qualified catalogues), selection of processing data methods and the creation of standards and norms that will be codified in the legislative;

- To ensure qualified research of disasters targeted to human security and an improvement in population education;

- With regard to the lessons from Fukushima to improve the methods associated with the determination of terms of references for design, construction and operation of technological buildings, equipment and infrastructures, deterministic and stochastic approaches must be supplemented by expert judgement that considers the influence of epistemic uncertainties;

- To improve: system of management of territory and objects; and integral risk management because procedures applied so far do not consider 


\begin{tabular}{|c|c|}
\hline & $\begin{array}{l}\text { cross-cutting risks, which are the cause of cascading failures of complex } \\
\text { systems; } \\
\text { - To operate systematic disaster monitoring; to create legislation } \\
\text { for the prevention, preparedness, response and renovation with special } \\
\text { attention to the response to critical situations (crisis management, } \\
\text { warning systems etc.); } \\
\text { - To study disaster characteristics in-depth; to improve the population } \\
\text { education with the aim of reducing its vulnerability to these disasters; } \\
\text { - To propose and implement sanctions for the contamination of air, water, } \\
\text { soil and rock mass; } \\
\text { - To propose response plans for the erosion of soil and rock massifs; } \\
\text { - To find the safeguard procedures for landscape uniformity; } \\
\text { - To apply effective protective measures and activities of supply chains. }\end{array}$ \\
\hline $\begin{array}{l}\text { Expected most } \\
\text { needed topics } \\
\text { of future } \\
\text { security } \\
\text { research }\end{array}$ & $\begin{array}{l}\text { To find a way how to implement into practice the strategic management } \\
\text { of integral safety that is systemic and proactive and it is not influenced } \\
\text { by lobbyists and other insisting groups. } \\
\text { To find a way how to implement professional knowledge for the benefit } \\
\text { of the public interest. } \\
\text { To specify the cases in which the system "JUST IN TIME" is impossible } \\
\text { to use from the viewpoint of human survival. } \\
\text { To find a way for: the reduction of big impacts of the brain drain } \\
\text { and the exodus of professionals - the creation of experience databases, } \\
\text { elimination of reasons for migration, such as poverty, climate change } \\
\text { and hunger, establishment of comprehensive migration policy - e.g. } \\
\text { measures and activities for the case of sharp climate change, } \\
\text { deforestation, desertification, biodiversity loss, etc. } \\
\text { To propose human countermeasures against disasters and their impacts, } \\
\text { if possible. }\end{array}$ \\
\hline
\end{tabular}

From the analysis in Table 1 it follows that many critical situations in the human system are connected with the management of disasters for which humans are responsible behaviour of humans; human factors; and disturbances in human society behaviour. Generally it is possible to say that the cause of critical situations are organisational accidents that are connected with a human factor; especially with phenomena such as corruption; abuse of power; suppression of the public interest; low respect to knowledge and engineering experiences; and low professional level of management. Their consequences are: government default; technologies failures; infrastructure failures; research failure; social system failure; decay of human society into intolerant groups; increasing number of impoverished people seniors, dossiers, jobless - problem young people who are out of work and without education; disturbances of daily civil protection human needs; disturbance of daily civil protection, human security and public welfare; disuse of technology, space militarization - real data are shown in Table 2.

Table 2: Phenomena that cause the disturbance of social relations, public welfare and human security.

\begin{tabular}{|l|l|}
\hline Domain & Defects leading to critical situations \\
\hline $\begin{array}{l}\text { Top } \\
\text { governance }\end{array}$ & $\begin{array}{l}\text { The domain management: is predetermined to political and military } \\
\text { aspects; is short of a human dimension and gives low support to EU }\end{array}$ \\
\hline
\end{tabular}




\begin{tabular}{|c|c|}
\hline & $\begin{array}{l}\text { inhabitants; does not govern on the basis of qualified data processed } \\
\text { by qualified methods; is often determined by fixed ideas without real } \\
\text { assessment of their realisation; is based on the image that all is stationary } \\
\text { and it does not respect dynamic development of the world that is necessary } \\
\text { to prepare for the possible extreme scenarios and measures for human's } \\
\text { survival; and is not realised on the principle "Safety management system } \\
\text { for system of systems". }\end{array}$ \\
\hline $\begin{array}{l}\text { Technical } \\
\text { domain }\end{array}$ & $\begin{array}{l}\text { In domain management: no standards and norms for underground and high- } \\
\text { rise buildings with regard to human security and public welfare; missing } \\
\text { essential services provided to the citizens; scenarios for decision-making } \\
\text { are prepared only by simulation without verification with use of real data - } \\
\text { sometimes scenarios used were derived for different conditions, i.e. } \\
\text { conditions of technology transfer were not fulfilled; no norms } \\
\text { and standards for interoperability; no standards and norms for the co- } \\
\text { operation of diverse systems; no co-ordinated emergency plans on all levels } \\
\text { (EU-wide to regional) - all must be on a professional level respecting } \\
\text { knowledge and experiences, continuity and contingency plans. }\end{array}$ \\
\hline $\begin{array}{l}\text { Organisational } \\
\text { domain }\end{array}$ & $\begin{array}{l}\text { In domain management: missing the effort directed to the reduction } \\
\text { of weakness (low number of resources, contamination of environment, } \\
\text { work price, unemployment) and to the use of strength (qualified technician } \\
\text { population); no effective tools against corruption, power misuse, lobbying } \\
\text { etc.; missing the support of co-operation on mutual partner principle; } \\
\text { missing the basis for mutual understanding and mutual co-existence; } \\
\text { no effective international teams of first responders; no basis for close co- } \\
\text { operation of first responders; no norms and standards for interoperability. }\end{array}$ \\
\hline $\begin{array}{l}\text { Knowledge } \\
\text { domain }\end{array}$ & $\begin{array}{l}\text { In the knowledge domain used for decision-making: missing systematic } \\
\text { respect to present world nature - dynamic open system of systems; low } \\
\text { effort is directed to the collection of qualified data on disasters } \\
\text { and on lessons learned from responses to extreme disasters; } \\
\text { is an underestimation of disasters at disasters' management; is neglecting } \\
\text { the creeping disasters such as ground water stores, contamination of human } \\
\text { food chains etc.; no qualified disasters scenarios for decision making. }\end{array}$ \\
\hline
\end{tabular}

A proposal for solving the above-mentioned problems consists of the finding a way how to implement in decision-making and governance of public affairs: a systematic use of knowledge and experiences at decision-making; strategic safety management and strategic safety engineering based on the system of system approach and on principles integral safety, which are based on integral risk management and trade-off with risk with the aim of averting organisational accidents; the human dimension into governance (daily public protection and public protection at normal, abnormal, and critical situations); rules for removing corruption, lobbying and the abuse of power; the solidarity principle; responsible co-operation among partners; good governance based on qualified data and on strategic, systemic and proactive management; systematic inspection by professionals, deputies and by the public; legislatively supporting the public's interests in the state and sector management; solution of possible conflicts through peaceful means; special family politics, ensuring the availability of further education, etc. It is also necessary to find a way how to establish and implement into daily practice the basic EU functions, because the economic basis, political and military bases are not sufficient for the security of EU inhabitants and for public welfare. For all these problems solving them is necessary to ensure: systematically building the knowledge base; systematically building material and a technical base; qualified engineering procedures; management based on qualified 
data; realising EU governance that supports the EU inhabitants. The most effective seems to be a systemic prevention of organisational accidents that lead to government defaults on all levels. It is necessary to stop talking and to work with the goal of "security and the sustainable development of humans".

\section{CONCLUSION}

The formulation of tasks for future research is based on the philosophy that each responsible government must protect inhabitants both in daily and in critical situations, i.e., the EU must also preserve the basic functions of a state; the real tasks are given for each public protected asset separately (Demster, 1967). The basic requirement is so that the research: was targeted, i.e., the already-known was not researched without good reason; sought and solved open problems, namely correctly with regard to current knowledge and experiences on ensuring the safe community and its sustainable development; demanded objective results under given conditions, i.e., to systematically present the results in front of a relevant expert community and to make them be subject to public opponent control. With this, plagiarism can be avoided, the real protection of intellectual property will be ensured and the development of creative abilities of individuals who have a creative potential and who are willing to give it for the benefit of the EU and its inhabitants' development will be supported; and would not distort the results - the style "the fundamental is what an authority says" holds development back. Therefore, it is necessary not to dissimulate conflicts among outcomes of projects since their existence is normal. Under the effort of finding the right solution, it is necessary to make it a subject of a thorough investigation with the aim of finding the causes of problems and to define an optimal solution for them within given conditions and within the given possibilities. The main task of future EU security research is to create systems for knowledge-based decisions and effective utilisation of land and nature. Therefore, the EU must remove prejudice in favour of lobbying groups the interest of which may be different from the public interests. The main deficiencies in the EU disasters' management are the following items: all hazard approaches are not systemically applied; some disasters are underestimated (mainly in the social domain); systemic, strategic and proactive management is not always implemented into practice; co-existence of systems with a different nature is not followed; gaps in risk management, risk engineering and in a trade-off with risks; present research does not determine priority orientations, its targets are influenced by politicians or lobbies; application procedures and orientation of strategies are not regularly verified; a reasonable strategy for disaster management is missing; the disaster management does not often respect disaster life cycles; accent to problem solving is missing, still being merely a lot of discussions on the problems; a lack of resources; a lack of instruments for ensuring EU finance stability; and a lack of management supporting public protection and sustainable development.

\section{REFERENCES}

Binková, P., Horáková, A., Procházková, D., 2012. The Comparison of Strategies Used in Internal Security Domain in the European Unions and in the Czech Republic on the Criminal-Police Segment. In Požární ochrana 2012. Ostrava: SPBI, pp. 21-25. ISBN 978-80-7385-115-6.

Demster, A. P., 1967. Upper and Lower Probabilities Induced by a Multivalued Mapping. The Annals of Mathematical Statistics, 38 (5), pp. 325-339. 
EU, 2004. Safe Community. PASR projects. Brussels: EU.

FEMA, 1996. Guide for All-Hazard Emergency Operations Planning. State and Local Guide (SLG) 101. Washinton: FEMA.

Gleick, J., 1996. Chaos, Origin of New Science. Brno: Ando Publishing, 1996. ISBN 8086047-04-0.

Lucas, Ch., 2006. Quantifying Complexity Theory [online]. [cited 2013-02-03]. Retrieved from: http://www.calresco.org/lucas/quantify.htm

Mayers, R. A., 2009. Encyclopedia of Complexity and Systems Science. Berlin: Springer. ISBN 978-0-387-75888-6.

Ott, E., 2012. Chaos in Dynamical Systems. New York: Cambridge University Press. ISBN 0521-01084-5.

Procházka, J., Procházka, Z., Ř́íha J., Procházková, D., 2012. Screening pro potřeby ř́zení bezpečnosti území. In Ochrana obyvatelstva - nebezpečné látky 2012. Ostrava: SPBI, pp. 127-131. ISBN 978-80-7385-109-5. ISSN 1803-7372. (in Czech)

Procházková, D., 2007. Methodology for Assessment of Costs on Renovation of Property Affected by Natural or Other Disaster. In SPEKTRUM XI. Ostrava: SPBI. 251 p. ISBN 978-80-86634-98-2.

Procházková, D., 2011. Strategic Management of Safety of Territory and Organisation. Praha: ČVUT. 483 p. ISBN 978-80-01-04844-3.

Procházková, D., 2012a. Facts for the EU Security Concept. Transactions of the VŠBTechnical University of Ostrava, VII (1), pp. 59-64. ISSN 1801-1764.

Procházková, D., 2012b. Critical Infrastructure Safety. Praha: ČVUT, p. 312. ISBN 978-8001-05103-0.

Procházková, D., 2012c. Principles of Mitigating and Managing Human System Risks. Information \& Security, 28 (1), pp. 21-36. ISSN 0861-5160.

Procházková, D., 2012d. Results of Selected Methods Evaluation. SPEKTRUM, 11 (2), pp. 47-51. ISSN 1211-6920. ISSN 1804-1639.

Procházková, D., Kopecký, Z., 2012. Problems of Bank Sector. In Požární ochrana 2012. Ostrava: SPBI, pp. 250-252. ISBN 978-80-7385-115-6.

Procházková, D., Pešková, I., 2012. Open Problems at Social Domain Management. In Požární ochrana 2012. Ostrava: SPBI, pp. 257-261. ISBN 978-80-7385-115-6.

Procházková, D., Říha, J., 2012a. Level of Management of Processes by Which the Environment React to Human Activities. In Požární ochrana 2012. Ostrava: SPBI, pp. 262-265. ISBN 978-80-7385-115-6. 
Procházková, D., Ř́ha, J., 2012b. Selected Security Problems of Supply Chains. In Požární ochrana 2012. Ostrava: SPBI, pp. 266-269. ISBN 978-80-7385-115-6.

Procházková, D., Ř́ha, J., 2012c. Scenarios of Selected Disasters. In Ochrana obyvatelstva nebezpečné látky 2012. Ostrava: SPBI, pp. 153-157. ISBN 978-80-7385-109-5. ISSN 1803-7372.

Procházková, D., Bartlová, I, Šenovský, M., 2011. Data on Impacts of Selected Disasters Collected by Combination of Method What, If with Method of Case Study for Decisionmaking Support. In Požární ochrana 2011. Ostrava: SPBI, pp. 288-291. ISBN 978-807385-102-6.

Procházková, D., Šenovský, M., Bartlová, I., 2012. Framework for Public Protection in the EU. In Ochrana obyvatelstva - nebezpečné látky 2012. Ostrava: SPBI, pp. 158162. ISBN 978-80-385-109-5. ISSN 1803-7372.

Procházková, D., Šenovský, M., Mozga, J., 2012. Problems of Public Protection in the EU. In Požární ochrana 2012. Ostrava: SPBI, pp. 270-274. ISBN 978-80-7385-115-6.

Procházková, D., Mozga J., Richter, R., Procházka, Z., Procházka, J., 2012. Defects At Natural Disasters Management. In Požární ochrana 2012. Ostrava: SPBI, pp. 239245. ISBN 978-80-7385-115-6.

Procházková, D., Richter, R., Procházka, Z., Procházka, J., 2012. Management of Disasters Connected With Technologies and Infrastructures. In Požární ochrana 2012. Ostrava: SPBI, pp. 246-249. ISBN 978-80-7385-115-6.

Procházková, D. et al., 2012. FOCUS project study - FOCUS [online]. [cited 2013-02-04]. Retrieved from: http://www.focusproject.eu/documents/14976/-5d763378-1198-4dc986ff-c46959712f8a

Shafer, G. A., 1976. Mathematical Theory of Evidence. Princeton: Princeton University Press. $292 \mathrm{p}$.

United Nation, 1994. Human development report [online]. New York: United Nations [cited 2013-02-03]. Retrieved from: www.un.org

Zadeh, L. A., 1975. The Concept of a Linguistic Variable and its Application to Approximate Reasoning I, II, III. Inf. Sci., (8), pp. 199-257, pp. 301-357, (9), pp. 43-80. 